gramme, or with meridian instruments, are requested kindly to communicate their observations to me as soon as they can conveniently do so, and if possible, in detail. A brief description of the micrometer and methods of illumination employed and of the screw error determinations should be added for publication.

Royal Observatory Cape of Good Hope I 882 Oct. 21.

David Gill.

\title{
Bahnbestimmung des Cometen 1882 I (Wells).
}

Die der Berechnung zu Grunde gelegten Normalorte und die Sonnencoordinaten sind folgende:

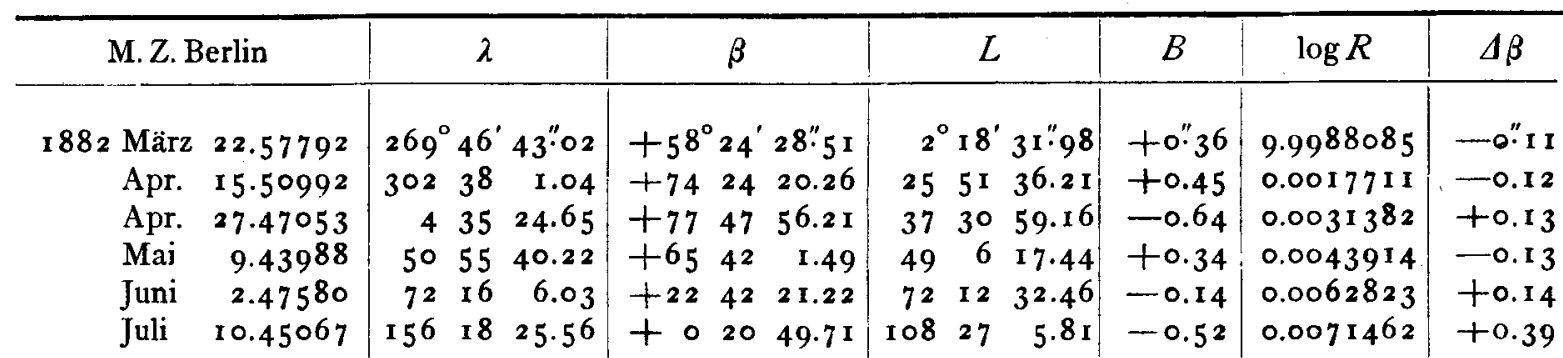

Die Vergleichung der Beobachtungsdaten, aus welchen die Normalorte abgeleitet sind, mit der aus den Elementen von Dr. Lamp berechneten Ephemeride im Sinne Beob.-Rechn. ergab

\begin{tabular}{|c|c|c|c|}
\hline & & $d \alpha$ & $d \delta$ \\
\hline \multirow[t]{6}{*}{ März 22} & Bothkamp & $+r s_{9}$ & $+1 " 50$ \\
\hline & Odessa & +2.25 & $-4.5^{2}$ \\
\hline & Odessa & +2.45 & $-28 I$ \\
\hline & Paris & +1.78 & $-1.5^{2}$ \\
\hline & Kiel & +2.01 & -3.09 \\
\hline & Cambr. (Mass.) & +1.30 & +0.69 \\
\hline \multirow[t]{6}{*}{ Apr. I 5} & Dresden & +1.09 & -0.65 \\
\hline & Dresden & +1.18 & -1.61 \\
\hline & Leipzig & +0.93 & +3.27 \\
\hline & Königsberg & +2.41 & +8.35 \\
\hline & Clinton & +1.16 & +5.35 \\
\hline & Cambr.(Engl.) & +1.49 & $-1.5^{2}$ \\
\hline \multirow[t]{4}{*}{ Apr. 27} & Kiel & $+\circ 36$ & +9.75 \\
\hline & Lyon & -0.19 & +7.44 \\
\hline & Kiel & +0.59 & +8.20 \\
\hline & Cambr. (Engl.) & to.10 & +8.45 \\
\hline
\end{tabular}

\begin{tabular}{|c|c|c|c|}
\hline & & $d \alpha$ & $d \delta$ \\
\hline \multirow[t]{6}{*}{ Mai 9} & Kiel & +0.07 & +22.52 \\
\hline & Kiel & +1.23 & +24.71 \\
\hline & Nicolaiew & +2.20 & +25.37 \\
\hline & Lyon & +1.47 & +25.65 \\
\hline & Lyon & $-0.3^{\circ}$ & +18.12 \\
\hline & Coll. Ront. & +0.70 & +24.89 \\
\hline \multirow[t]{5}{*}{ Juni 2} & Kiel & +1.55 & +23.79 \\
\hline & Dresden & +1.22 & $+25 \cdot 3^{8}$ \\
\hline & Plonsk & +0.93 & +22.79 \\
\hline & Warschau & +1.18 & +22.29 \\
\hline & Christiania & +1.10 & +25.40 \\
\hline \multirow[t]{3}{*}{ Juli Io } & Arcetri & +1.68 & -25.33 \\
\hline & Coll. Rom. & +1.60 & -29.12 \\
\hline & Washington & +2.06 & -20.78 \\
\hline
\end{tabular}

Die Sonnenbreiten sind durch die Anbringung der kleinen Correctionen an die Breiten des Cometen aus der Rechnung weggeschafft worden. Diese Correctionen sind in der Columne $\Delta \beta$ angesetzt.

Nach der Methode der Variation des Verhältnisses der geocentrischen Distanzen fand ich die folgenden Elemente:

$$
\begin{aligned}
& T=\text { I } 882 \text { Juni } 10.56682 \text { mittl. Berl. Zeit }
\end{aligned}
$$

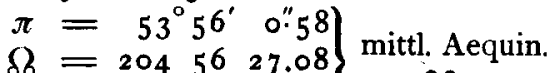

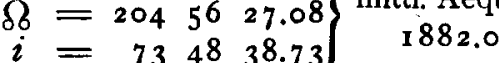

$$
\begin{aligned}
& \log q=8.783^{6} 786 \\
& \frac{\mathrm{r}}{a}=+0.0001107 . \mathrm{x}
\end{aligned}
$$


mit den folgenden übrig bleibenden Fehlern (im Sinne Beob.-Rechn.)

\begin{tabular}{|c|c|c|c|}
\hline März & 22 & $\cos \beta d \lambda=$ & $d \beta=$ \\
\hline Apr. & I 5 & -0.09 & -1.16 \\
\hline Apr. & 27 & -0.71 & $+\mathrm{r} .63$ \\
\hline Mai & 9 & +3.40 & +2.10 \\
\hline Juni & 2 & +1.63 & -0.09 \\
\hline & 10 & 0.0 & 0.0 \\
\hline
\end{tabular}

Wien 1882 November 23.

Stefan Wolyncervicz.

\section{Beobachtung des Schweifes des grossen Septembercometen 1882.} Auszug aus einem Schreiben des Herrn $W$. G. Lettsom an den Herausgeber.

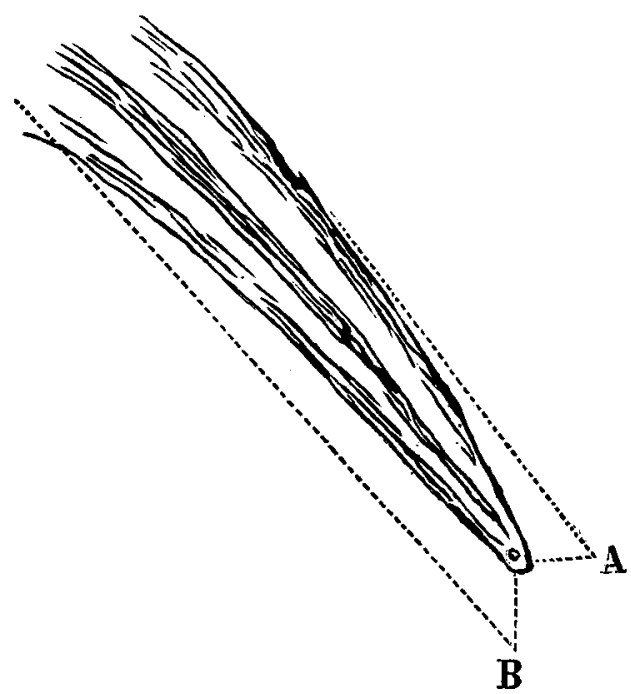

Honizon.

among us as a trustworthy observer, is at present engaged as assistant of one of the observers forming the British Expedition to Brisbane for the forthcoming Transit.

Being now on the voyage out, he on the $3^{\text {th }}$ September despatched a letter to me from Dobson's Bay, about 40 Miles from Melbourne, wherein he gives a very interesting account of the Great Comet, first seen on September $\mathrm{I}_{4}$ and then says,

sbut the most singular thing about it is that the comet, as seen to the naked eye, is only the nucleus or kernel, so to speak, of a larger cometic form seen in the glass. The Comet seems enclosed in a large and faint envelope, which, singular to say, does not take the curved
In Nr. 2468 of the A. Nachr. Dr. J. F. J. Schmidt describes and illustrates by a lithograph a nebulous body perceived, sketched and measured by him, upon the $9^{\text {th }}, 10^{\text {th }}$ and $I{ }^{\text {th }}$ of October, in the vicinity of the Great Septembercomet.

Dr. Schmidt, in the same article, expresses a hope that this phenomenon will also have attracted the notice of persons situated South of the European Observatories.

That hope has been already fulfilled, or to speak more correctly Dr. Schmidt's observations of the $9^{\text {th }}, 10^{\text {th }}$ and $I^{\text {th }}$ October confirm, as will be seen from what follows, the earlier observations by Mr. Grover of the same phenomenon.

Mr. Grover, who is well known figure of the Tail, but shows a straight outline, and projects in front on either side of the nucleus, ending in two points $A$ and $B$. The sector enclosed between these two points looks quite black, as if the nucleus cast a shadow before it, but probably in a powerful telescope this part would be filled by a faint light. \&

II made a sketch of the Comet, as seen from the bridge of the Steamer.s

Herewith I beg to forward you Mr. Grover's copy of his sketch.

London 1882 Nov. 25.

W. G. Lettsom.

Bemerkung. Die von dem Herrn Verfasser mitgetheilte Beobachtung bezieht sich offenbar nicht auf Dr. Schmidt's cometarische Nebelmasse vom 9., ro. und Ir. October (vergl. A. N. 2468 und die zugehörige Zeichnung), sondern auf die höchst merkwürdige Verlängerung des Schweifes, ïber das Kopfende des Cometen hinaus, in der Richtung nach der Sonne. Die lithographische Darstellung (Nr. 2468) des Cometen am Ir. Oct. giebt leider die Originalzeichnung sehr unvollkommen wieder; nach letzterer befand sich der Comet mit seinem hellen Schweife gewissermassen in einem Nebelrohre. Die Beobachtung des Herrn Grover stimmt hiermit uberein. Auch in der Note des Herrn Ch. André, A. N. 2470, vom 1 2. Oct. ist diese sonderbare Erscheinung angedeutet. Herr Tempel (Nr. 2468$)$ und Herr Ricco (Nr. 2469) haben übrigens dieselbe ebenfalls bemerkt. 